\title{
THE DSU ARTICLE 3.8 PRESUMPTION THAT AN INFRINGEMENT CONSTITUTES A PRIMA FACIE CASE OF NULLIFICATION OR IMPAIRMENT: WHEN DOES IT OPERATE AND WHY?
}

\author{
Arwel Davies*
}

\section{ABSTRACT}

This article considers the origin, meaning and current relevance of the Dispute Settlement Understanding (DSU) Article 3.8 presumption that a government measure which infringes World Trade Organization (WTO) obligations constitutes a prima facie case of nullification or impairment. It is argued that the prevailing interpretation of this provision is inconsistent with its plain language and may have contributed to the tendency of respondent states to invoke the presumption in order to undermine the fundamental principle that General Agreement on Tariff and Trade/WTO rules protect competitive opportunities rather than trade flows. The key to understanding the provision resides in the acknowledgment that the concept of nullification or impairment can be understood in two different senses depending on the stage in the proceedings at which it is relevant. While there is an isolated indication that the Appellate Body is edging closer to a re-interpretation of the provision, it is suggested that the dispute settlement process could be modestly simplified with some amendments to the DSU.

\section{INTRODUCTION}

This article considers a provision which has caused a great deal of confusion in the dispute settlement process. Article 3.8 of the Dispute Settlement Understanding (DSU) provides as follows:

In cases where there is an infringement of the obligations assumed under a covered agreement, the action is considered prima facie to constitute a case of nullification or impairment. This means that there is normally a presumption that a breach of the rules has an adverse impact on other Members parties to that covered agreement, and in such cases, it shall be up to the Member against whom the complaint has been brought to rebut the charge.

\footnotetext{
* Senior Lecturer, School of Law, Swansea University. E-mail: a.p.davies@swan.ac.uk. The author is grateful for comments provided by the anonymous reviewers.
} 
The Appellate Body has stated that Article 3.8, 'establishes a legal presumption that a breach of WTO rules constitutes nullification or impairment, ... in clear and unambiguous terms'. ${ }^{1}$ Contrary to this view, it is argued here that there is little which is clear about the operation of the presumption. While it has been considered in numerous cases, some of which having landmark status, the questions raised by the presumption have not been clearly articulated and resolved. Some of the Appellate Body's statements about the presumption convey a sense of ambivalence as can be detected by comparing the passages below.

In the original EC - Bananas III dispute, the panel and the Appellate Body relied on the conclusions of the GATT panel in US - Superfund to find that proving the absence of actual trade effects is insufficient to rebut the presumption of nullification or impairment under Article 3.8 of the DSU. ${ }^{2}$

The text of Article 3.8 of the DSU suggests that a Member may rebut the presumption of nullification or impairment by demonstrating that its breach of WTO rules has no adverse impact on other Members. Trade losses represent an obvious example of adverse impact under Article 3.8. ${ }^{3}$

The source of this ambivalence is uncertainty about two related matters; these being the stage in the proceedings during which, and the purpose for which, the presumption and the possibility of rebuttal operate. In turn, these uncertainties revolve around the concept of nullification or impairment (hereafter NOI), and the tendency to lose sight of the different senses in which this concept can be understood.

The term NOI is first used entirely interchangeably with the term 'infringement'. This interchangeability can be explained with reference to language such as NOI of the benefits accruing to World Trade Organization (WTO) Members directly or indirectly under the covered agreements. ${ }^{4}$ The exact nature of these benefits depends on the provision in question. In respect of core General Agreement on Tariff and Trade (GATT) obligations such as the prohibition on quantitative restrictions (Article XI), national and most favored nation treatment (Articles III and

${ }^{1}$ WTO Appellate Body Reports, European Communities - Regime for the Importation, Sale and Distribution of Bananas - Second Recourse to Article 21.5 of the DSU by Ecuador (EC - Bananas III (Article 21.5 - Ecuador II)) (adopted 11 December 2008) WT/DS27/AB/RW2/ECU, and Corr.1/European Communities - Regime for the Importation, Sale and Distribution of Bananas Recourse to Article 21.5 of the DSU by the United States (EC - Bananas III (Article 21.5 - US)) (adopted 22 December 2008) WT/DS27/AB/RW/USA and Corr.1, n 400.

${ }^{2}$ Ibid para 458.

${ }^{3}$ WTO Appellate Body Report, European Communities - Export Subsidies on Sugar (EC - Export Subsidies on Sugar) (adopted 19 May 2005) WT/DS265/AB/R, WT/DS266/AB/R, WT/DS283/ $\mathrm{AB} / \mathrm{R}$, para 289.

${ }^{4}$ This is representative of the language used in various provisions such as GATT Article XXIII.1 and DSU Articles 3.5, 22.8, 23.1 and 26:1. 
I), they have been defined in the case law as the expectation of equal competitive conditions and opportunities between the goods of different origins which are being compared. The relevant cases are so replete with statements to this effect ${ }^{5}$ that it has been possible for the Appellate Body to approve the generalization that, 'WTO rules are not concerned with actual trade effects, but rather with competitive opportunities' ${ }^{6}$ This statement applies more directly to the provisions above than it does, for example, to procedural obligations in the trade remedies context. At issue in Guatemala - Cement (I) was the obligation in Article 5.5 of the Anti-Dumping Agreement for authorities to notify the exporting Member of a possible dumping investigation. The panel noted that the function of this requirement is to, 'ensure that interested parties ... are able to take whatever steps they deem appropriate to defend their interests'; a statement which identifies the specific benefit protected by the provision. ${ }^{7}$ If there is a difference between these contexts, ${ }^{8}$ then there is also an overarching way of thinking about the benefit which is impaired by an infringement of any obligation. Complaining states in a number of cases have identified this benefit. An example from the WTO cases is Thailand's contention that 'the "most fundamental benefit" accruing to a WTO Member under the provisions of the covered agreements is "the benefit of their observance in good faith by the other Members" ".

For present purposes, it matters little whether the precise benefit which is nullified or impaired varies as between different provisions, or whether an overarching view can be adopted. This is because the examples above have something in common. Once it is known that a provision has been infringed, it is also known that the benefit protected by this provision has been nullified

${ }^{5}$ A compilation of these GATT and WTO cases is provided in WTO Panel Report, United States - Section 110(5) of the US Copyright Act (adopted 27 July 2000) WT/DS160/R, n 163.

${ }^{6}$ EC - Bananas III (Article 21.5 - Ecuador II), EC - Bananas III (Article 21.5 - US), above n 1, para 466.

7 WTO Panel Report, Guatemala - Anti-Dumping Investigation Regarding Portland Cement from Mexico (adopted 25 November 1998), WT/DS60/R, para 7.42.

8 The existence of a difference between the benefits protected by core GATT obligations, and procedural obligations, is not something which has to be conceded. In Guatemala - Cement I, the reference to interested parties defending their interests can be seen as an aspect of preserving competitive opportunities so that the Appellate Body's statement about the nature of WTO rules need not be seen as an over-generalization.

${ }^{9}$ WTO Appellate Body Report, EC - Export Subsidies on Sugar, above n 3, para 83. In the GATT cases, the complainants in US - Superfund argued that 'one of the benefits accruing to them under the General Agreement certainly was the observance by other contracting parties of the fundamental GATT principle of national treatment'. GATT Panel Report, United States - Taxes on Petroleum and Certain Imported Substances (US - Superfund) (adopted 17 June 1987) L/6175, BISD 34S/136, para 3.1.8. Similarly, Japan argued in EC - Audio Cassettes "the "benefit" nullified was Japan's right that Parties to the Agreement observe the Agreement's requirements before levying anti-dumping duties against exporters.' GATT Panel Report, EC Anti-Dumping Duties on Audio Tapes in Cassettes Originating in Fapan (28 April 1995) ADP/ 136, unadopted, para 55. 
or impaired. In reality, if not always in appearance, the process of deciding whether there is NOI is an integral part of the analysis of whether there is an infringement. In other words, the benefits intended to be protected by the GATT/WTO legal system are primarily embodied in the provisions of the covered agreements.

For shorthand, this meaning of NOI will be referred to as 'the infringement sense'. As is already evident, this meaning applies when the term NOI is used during, or immediately after, the stage in the proceedings when the existence of an infringement is discussed. The prevailing view in the case law is that Article 3.8 bears this meaning and operates in this context.

NOI is also understood in the different sense of adverse impact on trade flows later in the proceedings when the availability and scope of the remedy (usually the suspension of concessions) becomes relevant should the respondent state fail to promptly withdraw the offending measures. In practice, the clearest evidence of such an adverse impact is a reduction in trade volumes resulting from the successfully challenged measures. However, there could also be an adverse impact on trade flows where trade volumes increase, provided it can be established that trade volumes are not as high as they would otherwise have been.

The two meanings need to be distinguished because there can be an infringement (and therefore NOI in the infringement sense) whether or not there is an accompanying adverse impact on trade flows. The very matter which is pivotal in suspension proceedings is formally irrelevant in infringement proceedings, even though the Treaty text refers to NOI in both areas.

If the reference to NOI in Article 3.8 is understood in the infringement sense, it must then be accepted that the provision can only operate as an irrebuttable presumption that an infringement constitutes a case of NOI. It is perhaps not a stretch of the imagination to say that most panels have understood, and that the Appellate Body understands, Article 3.8 in this way. However, the fact that it is formulated as a rebuttable presumption leads to the expression of more guarded views which keep alive the theoretical possibility of rebuttal. This leads respondent states to attempt rebuttal, perhaps because they genuinely misunderstand this to be possible, or perhaps because they hope that a panel will make a mistake in their favor, even though they fully understand the irrebuttable nature of the presumption. Such a mistake is rather unlikely to occur, but not inconceivable. While it is generally considered that the presumption has never been rebutted, the panel in EC - Export Subsidies on Sugar erroneously thought otherwise. ${ }^{10}$

${ }^{10}$ WTO Panel Report, EC - Export Subsidies on Sugar, above n 3, n 675 to para 7.370. In this note, the panel states that the Article 3.8 presumption, '. . . has never been rebutted except in the exceptional panel report on US - Section 301 Trade Act.' However, Article 3.8 was not mentioned in US - Section 301 Trade Act, and rightly so, for it can only apply '[i]n cases where 
These observations provide a basis for asking whether Article 3.8 can be interpreted to enable its operation as a genuinely rebuttable presumption.

This could be achieved by abandoning the prevailing interpretation of Article 3.8 as a presumption of NOI in the infringement sense which operates during or immediately after the infringement analysis. Instead, it could be interpreted as a presumption that an infringement constitutes a prima facie case of NOI in the sense of adverse impact on trade flows, and as operating at the commencement of suspension proceedings. Here, there is a meaningful distinction between the issue of infringement, and that of whether the infringement causes NOI in the sense of adverse impact on trade flows. These will normally occur together, although an infringement which causes no adverse impact in terms of trade flows is also possible.

A powerful and simple argument can be made in favor of this approach by asking why a respondent state would wish to rebut the Article 3.8 presumption. The wording makes it possible to dispense with one possibility. Article 3.8 can only apply, '[i]n cases where there is an infringement', so that the issue of infringement is finalized before any presumption can apply. It follows that attempts at rebuttal have nothing to do with negating the infringement. The only other plausible explanation is that rebuttal is connected with the availability and scope of the remedy should the respondent state fail to promptly withdraw the infringing measures. Much would seem to follow from this realization. Article 3.8 should be understood as operating when the remedy is being decided upon, and NOI should be given the meaning which is usually attributed to it at this stage of the proceedings.

The further sections of this article explore and test the ideas introduced above, beginning with an identification of the case law origin of the presumption in Section II. It is argued that an irrebuttable presumption ought to have been established from the outset, so that the first enactment of the presumption in 1979 represented a failure to correct the mistake of a 1962 panel. An irrebuttable presumption would have reinforced the original rationale, and prevented respondent states from viewing the presumption as a means of undermining the principle that GATT/WTO rules are concerned with competitive opportunities rather than actual trade effects. Section III briefly traces the development of this case law principle from the very early years of GATT, up to its concretization in US - Superfund. ${ }^{11}$ This was the first occasion on which a panel was required to rule on the relationship between the 1979 presumption and the emphasis on protecting competitive opportunities. It is argued that some of the panel's reasoning was unconvincing by

there is an infringement...' In this case, the panel concluded that there was no infringement, so that the essential requirement which triggers the operation of Article 3.8 was not present.

11 US-Superfund, above n 9. 
reason of being at odds with the plain language of the presumption. An alternative analysis is suggested which would have laid to rest the premature reliance on the presumption by respondent states. Attention then turns in Section IV to a search for the elements of the suggested approach towards the presumption in the modern case law. These elements are, first, that NOI can be understood in two different senses; secondly, that an infringement constitutes a case of NOI and thirdly, that Article 3.8 operates at the commencement of suspension proceedings. Strong support for all but the third element is found. It is argued that the adoption of the third element would be more consistent with the plain language of the provision than the present approach. The closing recommendations in Section V question whether further developments should be left to the Appellate Body, or whether amendments to the DSU should be contemplated. The preference is for the latter option, and suggested revisions to the text are set out.

\section{TRACING THE ORIGIN OF THE PRESUMPTION}

The text of Article 3.8 is derived from the DSU's predecessor, the 1979 Understanding Regarding Notification, Consultation, Dispute Settlement and Surveillance (the 1979 Understanding). ${ }^{12}$ The relevant provision is contained in paragraph 5 of the Annex to this instrument which is entitled Agreed Description of the Customary Practice of the GATT in the Field of Dispute Settlement (paragraph 5). Surprisingly, the case law origin of this provision does not seem to have been identified in any of the cases in which paragraph 5 or Article 3.8 have been discussed. Indeed the wording of the provision has even been incorrectly attributed to the US - Superfund case. ${ }^{13}$ The correct attribution is the 1962 case of Uruguayan Recourse to Article XXIII. ${ }^{14}$ The panel's views were as follows:

14. In most cases Uruguay claimed that the maintenance of the trade measures by the other contracting parties had nullified or impaired benefits accruing to Uruguay under the General Agreement. The Panel thought it essential to have a clear idea as to what would constitute a nullification or impairment. In its view impairment and nullification in the sense of [GATT] Article XXIII does not arise merely because of the existence of any measures; the nullification or impairment must relate to benefits accruing to the contracting party 'under the General Agreement'.

15. In implementing the compensation provision of Article XXIII:2 [dealing with suspension of concessions] the CONTRACTING PARTIES

12 (Adopted on 28 November 1979), L/4907.

${ }^{13}$ Decision by the Arbitrators, European Communities - Regime for the Importation, Sale and Distribution of Bananas - Recourse to Arbitration by the European Communities under Article 22.6 of the DSU, WT/DS27/ARB, circulated 9 April 1999, para 6.11.

${ }^{14}$ GATT Panel Report, Uruguayan Recourse to Article XXIII (adopted 16November 1962) L/1923, BISD 11S/95. 
would therefore need to know what benefits accruing under the Agreement, in the view of the country invoking the provisions, had been nullified or impaired, and the reasons for this view. In cases where there is a clear infringement of the provisions of the General Agreement ... the action would, prima facie, constitute a case of nullification or impairment and would ipso facto require consideration of whether the circumstances are serious enough to justify the authorization of suspension of concessions or obligations...

These passages establish the original rationale for the presumption which is to simplify the process by which complaining states can permissibly call for the establishment of a panel. This is not immediately apparent because of the importance the panel attributes to Uruguay spelling out exactly what benefits have been nullified or impaired. This identification is described as 'essential' in paragraph 14. The key point however is that this obligation evaporates in instances where there is a 'clear infringement' under paragraph 15. Thus the request for establishment can be framed in terms of allegations of how identified measures infringe certain provisions. There is no further need to explain what benefits have been nullified or impaired, and how.

This original rationale has been confirmed in the WTO case law. Among the issues before the panel in Mexico - Corn Syrup ${ }^{15}$ was the alleged insufficiency of the United States' request for a panel. The governing provision was Article 17.5(i) of the Anti-Dumping Agreement which requires the requesting Member to indicate, '. . how a benefit accruing to it, directly or indirectly, under this Agreement, has been nullified or impaired.... Mexico argued that these requirements could not be satisfied 'implicitly' and drew attention to the absence of the terms 'nullify' or 'impair' in the request for a panel. Citing DSU Article 3.8, the panel disagreed and considered that '.... request for establishment that alleges violations of the $\mathrm{AD}$ Agreement ... contains a sufficient allegation of NOI.... 16

There is a clear sense in both cases that the concept of NOI is of limited relevance at least in cases where infringements are alleged, as opposed to non-violation complaints. Yet the 1962 panel erred on the side of caution and established a presumption rather than an absolute rule. The panel therefore preserved the possibility of separate and additional discussion under the heading of NOI even when infringements have been confirmed. The preference for a presumption is highly questionable if it is accepted (as argued in the introduction and as developed further in Section IV.B.) that, if there is an infringement of a provision, there is necessarily also a NOI of the benefit which is protected by the provision. The only way to attempt to make sense of paragraph 15 is to claim that the panel was referring to NOI in the sense

\footnotetext{
${ }^{15}$ WTO Panel Report, Mexico - Anti-Dumping Investigation of High Fructose Corn Syrup (HFCS) from the United States (adopted 24 February 2000), WT/DS132/R.

${ }^{16}$ Ibid para 7.28.
} 
of adverse impact on trade flows; the sense which is relevant at the stage in the proceedings when the level of suspension of concessions is decided. However, this does not seem to be the panel's intention. While the panel makes references to suspension, there are also references to NOI of 'benefits accruing to the contracting party...' which is indicative of the infringement sense. This would seem to be what the panel intended bearing in mind that the case was about how complaining states can permissibly formulate their claims at the commencement of proceedings, and that a decision on suspension was explicitly deferred. ${ }^{17}$ Without the removal of the term 'prima facie', paragraph 15 does not make sense, so that the panel should have established an absolute rule. This would have reinforced the original rationale by fully aligning the issue of infringement with the concept of NOI.

Bearing these points in mind, it is regrettable that the panel's formulation was elevated to the status of Treaty language by the 1979 text. This resulted in attempts by respondent states to rebut the presumption in cases bearing no relation to those above which illustrate the original rationale. Had the mistake of the 1962 panel been corrected in the 1979 text, this would have been avoided and the overall process of dispute settlement would have been modestly simplified. As it stands, the enactment of the presumption is seen by respondent states as a means of undermining the principle that GATT/ WTO rules are not concerned with actual trade effects, but rather with competitive opportunities.

\section{THE 1979 PRESUMPTION AND ATTEMPTS TO UNDERMINE A FUNDAMENTAL PRINCIPLE}

This section first describes the origin and development of the emphasis on protecting competitive opportunities. It then addresses the tendency of respondent states to invoke the presumption in order to undermine this principle. This tendency is considered to be understandable and defensible based on the text of the presumption. The adequacy of the judicial response to this use of the presumption is then assessed with particular reference to the US - Superfund case.

\section{A. The protection of competitive opportunities and the consequent rejection of evidence relating to trade flows}

It is firmly established that the core GATT obligations can be infringed whether or not the challenged measures have had an impact on trade flows, or have resulted in trade damage or produced an adverse impact or trade effects. ${ }^{18}$ The first pronouncements to this effect made by half the

17 Uruguayan Recourse to Article XXIII, above n 14, para 20.

18 These phrases have been used interchangeably in the case law. 
members of the Working Party on Brazil - Internal Taxes ${ }^{19}$ in 1949, significantly pre-date the 1987 US - Superfund ${ }^{20}$ case which is usually cited as the landmark precedent in this area. At issue in Brazil - Internal Taxes was a law maintaining a tax differential of 100 per cent between certain domestic products and exactly the same imported products. The report did not provide a legal ruling in that it went no further than setting out the positions of both sides and that of the other delegates. One of the defenses presented by the Brazilian delegate, with which two other delegates agreed, was that 'unless damage to other contracting parties could be demonstrated, a breach of Article III could not be alleged'. The other three members disagreed, considering that '[W]hether or not damage was shown, taxes on imported products in excess of those on like domestic products were prohibited by Article III, and that the provisions of Article III were intended to prevent damage and not merely to provide a means of rectifying such damage. ${ }^{21}$ They went on to state that:

the absence of imports from contracting parties during any period of time that might be selected for examination would not necessarily be an indication that they had no interest in exports of the product affected by the tax, since their potentialities as exporters, given national treatment, should be taken into account... [T] he provisions of the first sentence of Article III, paragraph 2, were equally applicable whether imports from other contracting parties were substantial, small or non-existent. ${ }^{22}$

The first of a number of cases from the 1980s cast doubt on whether these pronouncements would gain a foothold and become part of the GATT acquis. At issue in the unadopted report in Spain - Soyabean Oil ${ }^{23}$ were Spanish consumption quotas specifying limits on the domestic consumption of soyabean oil. The panel considered that there could not be a violation of Article III:1 unless the challenged measures had an 'adverse effect' in the sense of restricting or limiting imports of soyabeans from the United States. As the statistics indicated a 'considerable increase of soyabean imports ...which did not show any signs of weakening', there was no violation. ${ }^{24}$ There was strong opposition to this ruling. Hudec described a request by the United States to the GATT Council that the report be merely noted instead of adopted. Indeed, as Hudec noted, 'the United States even offered to drop its complaint in exchange for wiping this ruling off the books'. At a

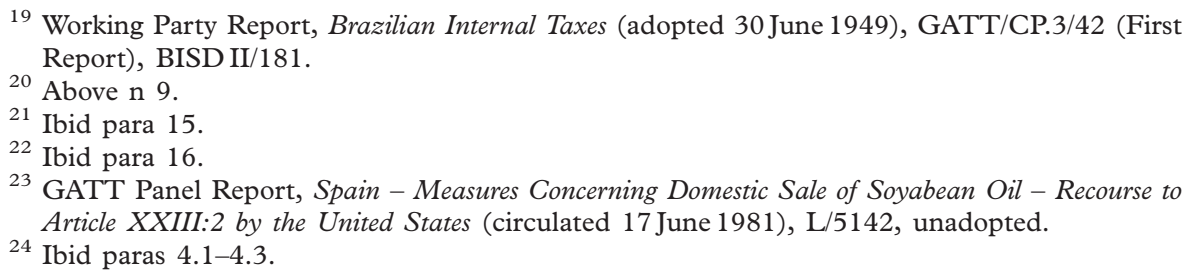


November 1981 meeting, 24 delegations spoke, of which 21 supported the US proposal. ${ }^{25}$

The next case in which the role of trade flows arose was Canada-FIRA. ${ }^{26}$ This came three years after Spain - Soyobean Oil, but sided with the views of the complainants in Brazil - Internal Taxes. In Canada - FIRA, the United States challenged the Canadian practice of entering into agreements with foreign investors involving preferences for the purchase of Canadian goods over imported goods. The panel found these commitments to be inconsistent with Article III:4 both in cases where the commitment was absolute, and in cases where the commitment was qualified, for example, by the condition that Canadian goods be 'competitively available'. ${ }^{27}$ The panel considered that this qualification would require a preference for Canadian goods where the competing imported and domestic goods were available on equivalent terms. The United States had made a persuasive argument here which, while not expressly approved be panel, could be described as an elaboration of its reasoning. According to the United States, '.... a firm subject to an undertaking with such a proviso was therefore likely to purchase Canadian goods even when they were less attractive than imported goods in order to avoid possible conflict with Canadian officials monitoring compliance who have a different perspective and apply different value judgements on these matters. ${ }^{28}$ The panel expressed an implicit approval of this argument in noting that the purchase requirements, 'tend to tip the balance in favour of Canadian products, thus coming into conflict with Article III:4. ${ }^{29}$

The panel's rejection of trade flows was hinted at in its conclusions. It was recognized that the purchase requirements may have reflected plans which the investors would have carried out in the absence of undertakings. ${ }^{30}$ In other words, the undertakings may not have had any actual impact on trade flows, but they still amounted to a violation based on what some members of the Working Party in Brazil - Internal Taxes described as the potentiality of an impact. The manner in which the panel elaborated on its conclusion was, however, unfortunate in the sense that it could be read as a step in the wrong direction. For the panel, it followed that, 'many of the undertakings, though technically in violation with the General Agreement, therefore possibly do not nullify or impair benefits accruing to the United States under the

25 Robert E Hudec, Enforcing International Trade Law. The Evolution of the Modern GATT Legal System (Butterworth Legal Publishers, New Hampshire 1993) 136.

${ }^{26}$ GATT Panel Report, Canada - Administration of the Foreign Investment Review Act (7 February 1984), L/5504, BISD 30S/140.

27 Ibid paras 5.8-5.9.

28 Ibid para 3.5 .

${ }^{29}$ Ibid para 6.3 .

30 Ibid para 6.4. This statement recognizes the plausibility of a Canadian defence that undertakings would only be given to the extent that 'they reflected a decision by the investor about how he intended to conduct his business in Canada' (para 3.6). 
General Agreement. ${ }^{31}$ This statement is at odds with the position argued for in this article - that once an infringement is confirmed, it necessarily follows that the benefit protected by the infringed provision has been nullified or impaired. As Roessler notes, '[I]n a multilateral trade order which prescribes conditions of competition and therefore does not guarantee trade results but trade opportunities, the application of the concept of nullification and impairment to violation cases cannot fulfill a useful function'. ${ }^{32}$

The reason why the panel arguably fell into error in this part of its reasoning might have been a failure to sufficiently distinguish two different enquiries. The first is whether there is an infringement/whether there is NOI of a protected benefit, while the second enquiry relates to the availability and extent of the remedy available in the event of recalcitrance in the removal of the infringement. The consideration of trade flows is only indispensably relevant under the second issue. As was noted by the panel in US Manufacturing Clause, '[C]onsideration of whether the circumstances of the case were serious enough to justify authorization of a suspension of obligations or concessions could not be addressed before the basic issue of conformity had been resolved. ${ }^{33}$

A final point about Canada - FIRA is that, by this time, the 1979 presumption had been enacted. This led the panel to believe that 'an evaluation of the trade effects was not directly relevant to its findings because a breach of a GATT rule is presumed to have an adverse impact on other contracting parties. ${ }^{34}$ This reference to the presumption is regrettable. The original rationale for the presumption was unconnected with the doctrine that GATT rules are concerned with competitive opportunities rather than with actual trade effects. This development was very nearly set in stone by this time so that the presumption was not required in this context. More problematically, however, it was not long before respondent states set about trying to rebut the presumption.

\section{B. The attempt to rebut the presumption in US - Superfund}

At issue in US - Superfund was a discriminatory tax with domestic petroleum being subject to a rate of 8.3 cents per barrel and the imported product being subject to 11.7 cents per barrel. This was challenged by Canada, the EEC and Mexico as inconsistent with GATT Article III:2 first sentence. The United States argued that this difference was too small to 'appreciably

31 Ibid para 6.4 .

32 Frieder Roessler, 'The Concept of Nullification and Impairment in the Legal System of the World Trade Organization', in Ernst-Ulrich Petersmann (ed) International Trade Law and the GATT/WTO Legal System, Studies in Transnational Economic Law, volume 11 (Kluwer Law International, London 1997) 125-42 at 141.

33 GATT Panel Report, United States Manufacturing Clause (adopted 15 May 1984), L/5609, BISD 31S/74, para 30.

${ }^{34}$ Canada-FIRA, above n 26, para 6.6. 
influence petroleum buyers' decisions' and 'to stimulate investments in domestic oil production'. The United States also considered that it would import approximately the same volume of petroleum as before in spite of the tax differential. The request was for a finding that benefits accruing to the complainants under the GATT had not been nullified or impaired on the basis of the absence of adverse trade effects. ${ }^{35}$

The panel dismissed this request in an entirely convincing passage which would later gain landmark status noting that '...Article III:2, first sentence, cannot be interpreted to protect expectations on export volumes; it protects expectations on the competitive relationship between imported and domestic products. A change in the competitive relationship contrary to that provision must consequently be regarded ipso facto as a NOI of benefits accruing under the General Agreement., ${ }^{36}$ In other words, there is an irrebuttable presumption that an infringement of the provision results in NOI of benefits protected under the GATT. However, the manner in which the panel attempted to reconcile this position with the 1979 presumption was unconvincing by reason of being at odds with the plain language of the presumption. Agreeing with the complainants, ${ }^{37}$ the panel noted that, 'the impact of a measure inconsistent with the General Agreement is not relevant for a determination of NOI' ${ }^{38}$ Contrary to this conclusion, the presumption seems to envisage an absence of 'adverse impact' leading to an absence of NOI. Paragraph 5 of the 1979 Understanding $^{39}$ is provided below. Within this provision, the underlined passages now constitute DSU Article $3.8 .^{40}$

5. In practice, contracting parties have had recourse to Article XXIII only when in their view a benefit accruing to them under the General Agreement was being nullified or impaired. In cases where there is an infringement of the obligations assumed under the General Agreement, the action is considered prima facie to constitute a case of NOI. A prima facie case of NOI would ipso facto require consideration of whether the circumstances are serious enough to justify the authorization of suspension of concessions or obligations, if the contracting party bringing the complaint so requests. This means that there is normally a presumption that a breach of the rules has an adverse impact on other contracting parties, and in such cases, it is up to the contracting parties against whom the complaint has been brought to rebut the charge... (emphasis added)

Whether one looks at the former or present text, 'NOI' is clearly and inescapably equated with 'adverse impact'. In turn, the latter phrase seems to

${ }^{35}$ US - Superfund, above n 9, para 3.1.3.

36 Ibid para 5.1.9.

37 Ibid para 3.1.6.

38 Ibid para 5.1.5.

39 Above n 12.

40 This is subject to a few immaterial differences such as the use of 'contracting parties' in the 1979 text while the present text refers to 'the Member'. 
convey the idea of something which is tangible, most obviously an actual impact on trade flows rather than merely a potential impact. The ordinary meaning therefore conveys the possibility of rebutting a presumption of NOI/ adverse impact, by demonstrating the absence of impact on trade flows resulting from an infringing measure.

If this seems heretical on the basis that few cases have been cited with approval more often than US - Superfund, the Appellate Body statement provided in the introduction can be recalled. Tellingly, US - Superfund was not cited by the Appellate Body when it observed that:

...Article 3.8 equates the concept of 'NOI' with 'adverse impact on other Members', although the DSU does not define 'adverse impact'... The text of Article 3.8 of the DSU suggests that a Member may rebut the presumption of NOI by demonstrating that its breach of WTO rules has no adverse impact on other Members. Trade losses represent an obvious example of adverse impact under Article 3.8. ${ }^{41}$

This statement could be described as an obiter dictum. The successfully challenged measures had resulted in very pronounced trade losses, ${ }^{42}$ and it can therefore be questioned whether this statement would have been made had there been a plausible argument that the impact on trade flows was minimal or non-existent. Nevertheless, the statement represents a clear acknowledgement of how Article 3.8 should be interpreted based on its plain language, a matter which cannot change in a predictable legal system based on the facts of individual cases. ${ }^{43}$

How then did the panel in US - Superfund come to agree with the complainants on the non-linkage between trade flows and the concept of NOI? The panel considered that, under paragraph 5 above, the adverse impact of a measure found to be an infringement was relevant only at the stage of the proceedings when the suspension of concessions was being considered, rather than at any earlier stage. ${ }^{44}$ This is indicated by the language which

41 EC - Export Subsidies on Sugar, above n 3, paras 288-9.

42 Ibid para 298 in which the Appellate Body refers to undisputed evidence 'suggesting that the EC sugar regime caused ... losses, for example, of US \$494 million for Brazil and US \$151 million for Thailand in 2002'.

43 A possible response to this position is that the Appellate Body has only provided 'trade losses' as 'an obvious example of adverse impact under Article 3.8', and that, therefore, they must surely be other examples including, perhaps, trade opportunities. This could be correct, although something which is an obvious example could also be the only example. Also, if the impediment of trade opportunities is an example of something which causes adverse impact, the Appellate Body's statement would be disingenuous. There would be no point in demonstrating the absence of trade losses if there is a further, and probably impossible, requirement to demonstrate the absence of an impediment to trade opportunities. The Appellate Body's statement is drafted more consistently with acknowledging the possibility of rebuttal than establishing its impossibility.

${ }^{44}$ US - Superfund, above n 9, para 5.1.4. Having quoted part of paragraph 5 the panel commented that, '...the 1979 Understanding does not refer to the adverse impact of a measure, 
appears between the underlined passages in paragraph 5. However, the fact that trade flows are only relevant at a certain stage in the proceedings does not change the position that paragraph 5 equates 'adverse impact'/trade flows with 'NOI'. My criticism is therefore that the panel did not work through the implications of its own vital realization. As it had correctly viewed the presumption as operating only during suspension proceedings, it was free to reinforce this point and thereby lay to rest premature attempts by respondent states to rebut the presumption.

This could have been achieved had the panel acknowledged the link in paragraph 5 between adverse impact and NOI and used this link as the departure point for its analysis. The panel would then have needed to posit that the concept of NOI can be understood in different senses depending on the stage in the proceedings at which it is relevant. The first sentence of paragraph 5 deals with the early stage in the proceedings during which complaining states decide whether to have recourse to Article XXIII. They are effectively advised only to initiate proceedings when there is NOI in the infringement sense, or (in recognition of the non-violation complaint) when NOI of benefits may have occurred even though there has not been an infringement. However, the remainder of the provision deals with the stage in the proceedings during which suspension is considered. Here, NOI is generally understood in the sense of adverse impact on trade flows. Using this approach, the panel could have reached a conclusion which would have been consistent with the text. The conclusion would have been that paragraph 5 does envisage that the presumption of NOI can be rebutted, by adducing evidence about the limited or non-existent impact of the measure on trade flows. A successful rebuttal would have no impact on the initial finding of an infringement. It would merely deprive the complainant of a remedy, or define and curtail the scope of this remedy.

Admittedly, this suggested approach to paragraph 5 would not have had the benefit of simplicity. It calls for the same term (NOI) to be understood in two different senses in the same provision (paragraph 5). However, the complexity of this approach can be weighed against several considerations. There is a strong argument that the panel's approach in US - Superfund was inconsistent with the plain language of paragraph 5 . This may have contributed to the unabated tendency of respondent states to prematurely invoke the presumption. ${ }^{45}$ The panel's reasoning has not been accepted, because it is not

and the possibility of a rebuttal, in connection with the power of the CONTRACTING PARTIES to make recommendations or give rulings on measures inconsistent with the General Agreement; it does so only in connection with the authorization of compensatory action'. Paras 5.1.4-5.1.5.

45 This is perhaps evidenced by Turkey's argument that, "WTO law requires that an alleged breach of a Member's right must have an economic impact on the complaining Member' and that the panel should therefore, 'ignore the conclusions of the panel in US - Superfund, and of 
entirely convincing. Paradoxically, a characteristic of the suggested approach is that it opens the flood gates by acknowledging that there is a presumption which is capable of being rebutted. However, both the stage in the proceedings during which, and the purpose for which, this can be done, is made expressly clear. The operation of a rebuttable presumption in the context of determining the level of suspension is theoretically sound, albeit that the chances of success are limited. Finally, the complexity of the suggested approach has now been removed by DSU Article 3.8. There is only one reference to NOI in this provision which can be understood exclusively in the sense of adverse impact on trade flows.

A further observation is that the suggested approach is at odds with the original rationale for the presumption. It can be recalled that this was to simplify the process by which states can call for the establishment of a panel. Therefore, as originally conceived, the presumption operated at the commencement of proceedings, rather than during suspension proceedings. However, paragraph 5, with its references to 'suspension of concessions' and 'adverse impact' does not itself resemble the type of the provision which would have given expression to the original rationale. A simple statement to the effect that, an allegation of an infringement constitutes an allegation of NOI, would have sufficed. The task is to make sense of paragraph 5 in the form in which it was enacted, and it has been argued that an alternative analysis to that preferred by the US - Superfund panel could have done more to clarify this area. Faced with a provision which obstructed rather than facilitated its conclusion, and knowing that it could not ignore or re-write paragraph 5, the panel adopted what it probably considered to be the only possible solution of finding that 'the presumption had in practice operated as an irrefutable presumption'. ${ }^{46}$ An alternative solution was however available.

\section{ELEMENTS OF THE SUGGESTED APPROACH}

The discussion now turns to a search for the elements of the suggested approach in the subsequent case law.

\section{A. NOI can be understood in two different senses}

The first element of the suggested approach is that the term NOI can be understood in two different senses. This is the least controversial element for which there is strong support in the case law notwithstanding an argument by the European Communities that the term has only one meaning. An explanation of the NOI in the infringement sense has been provided in

the Appellate Body in EC - Bananas III. WTO Panel Report, Turkey - Restrictions on Imports of Textile and Clothing Products (adopted 19 November 1999), WT/DS34/R, paras 194-5.

${ }^{46}$ US - Superfund, above n 9, para 5.1.7. 
the introduction. While some of the discussion below further illustrates this sense, the main purpose here is to justify the view that NOI is also understood as adverse impact on trade flows during proceedings to determine the level of suspension of concessions.

Within this stage of the proceedings, DSU Article 22.4 requires that the, 'level of the suspension of concessions ... shall be equivalent to the level of NOI'. Paragraph 6 foresees the possibility of disagreement on the level of proposed suspension and paragraph 7 empowers the appointed arbitrator/s to decide upon the issue of equivalence. Arbitrators must therefore attribute a financial value to the 'level of NOI' in order to determine the permissible level of suspension.

The arbitrators in US - Section 110(5) Copyright Act (Article 25) compiled the benefits nullified or impaired in all the previous DSU Article 22.6 arbitrations. They collectively read as '...losses in US exports of goods and losses by US service suppliers in services supply; losses by Ecuador of actual trade and of potential trade opportunities in bananas and the loss of actual and potential distribution service supply; foregone US and Canadian exports of hormone treated beef and beef products. ${ }^{47}$ In the subsequent US - Gambling (Article 22.6 - US) arbitration, the benefit nullified or impaired was found to be the annual revenue loss for Antigua in remote services for horseracing gambling and betting. ${ }^{48}$ In these arbitrations, the level of NOI was equated with the impact of the challenged measures on trade flows; the very matter which is irrelevant to whether there is NOI in the infringement sense earlier in the proceedings.

The reference to losses by Ecuador of 'potential trade opportunities' above in one of the arbitrations ${ }^{49}$ blurs the boundary between the two senses in which NOI can be understood. However, this reference does not significantly undermine the proposition that there are two distinct senses. In proceedings to initially determine whether there are infringements, the finding of a violation can be based upon an entirely hypothetical potential impact on competitive opportunities. The lack of any actual impact, and even the improbability of future impact, are immaterial. This was recently confirmed by the Appellate Body in the latest installment of the Bananas litigation:

In these proceedings, as in the original proceedings, the contested measure may not have actual trade effects because, at present, there are no exports

${ }^{47}$ Award of the Arbitrators, United States - Section 110(5) of the US Copyright Act - Recourse to Arbitration under Article 25 of the DSU (9 November 2001) WT/DS160/ARB25/1, n 39.

${ }^{48}$ Decision by the Arbitrator, United States - Measures Affecting the Cross-Border Supply of Gambling and Betting Services - Recourse to Arbitration by the United States under Article 22.6 of the DSU (21 December 2007), WT/DS285/ARB, paras 3.74 and 3.187.

49 Decision by the Arbitrators, European Communities - Regime for the Importation, Sale and Distribution of Bananas - Recourse to Arbitration by the European Communities under Article 22.6 of the DSU (24 March 2000), WT/DS27/ARB/ECU, n 52. 
of bananas from the United States to the European Communities. However, in order to determine whether the United States has suffered NOI, 'competitive opportunities' and, in particular, any potential export interest of the United States must be taken into account... As noted by the panel and the Appellate Body in the original proceedings, while present production in the United States is minimal, it could at any time start exporting the few bananas it produces to the European Communities. That this may be unlikely does not disprove that the United States is a potential exporter of bananas to the European Communities. ${ }^{50}$

In contrast, in suspension proceedings, to the extent that losses of potential trade opportunities are taken into account, they probably have to be sufficiently tangible to warrant the attribution of a financial sum to the losses. The arbitrators need to be able to posit that, without the measures, the relevant industry in the complaining state would probably have taken advantage of the greater opportunity to trade. Support for this suggestion can be derived from statements in a number of arbitrations on the need to avoid, "claims that are "too remote", "too speculative", or "not meaningfully quantified", 51

Finally in this section, the argument of the EC that there, '. . can be only one notion of "NOI" for the purposes of the DSU' is addressed. ${ }^{52}$ The EC drew support for its position from the following passage in the US - $1916 \mathrm{Act}$ (EC) (Article 22.6 - US) arbitration to determine the level of suspension of concessions:

...The original Panel determined that the 1916 Act 'nullifies and impairs benefits accruing to the European Communities.' In light of this conclusion, the level [of NOI for the purpose of suspension] must be something greater than 'zero', and it is a contradiction in terms to suggest otherwise. $^{53}$

This passage does seem to support the 'one notion' argument for it dismisses the possibility of the presence of NOI in the initial proceedings to determine whether there is an infringement, without some form of NOI which would justify the eventual suspension of concessions. However, the findings of

${ }^{50}$ EC - Bananas III (Article 21.5 - Ecuador II)), EC - Bananas III (Article 21.5 - US)), above $\mathrm{n}$ 1 para 469.

51 Decision by the Arbitrators, United States - Anti-Dumping Act of 1916, Original Complaint by the European Communities - Recourse to Arbitration by the United States under Article 22.6 of the DSU (24 February 2004), WT/DS136/ARB, para 5.57. The arbitrators found this guidance in earlier arbitrations.

52 WTO Panel Report, European Communities - Regime for the Importation, Sale and Distribution of Bananas - Recourse to Article 21.5 of the DSU by the United States (adopted 22 December 2008), WT/DS27/RW/USA and Corr.1, para 4.171.

53 Above n 51, para 5.50. 
the arbitrators provide an example of the very possibility which was dismissed.

For the purposes of suspension, it was found that, 'the amount of any final judgments entered against EC companies or their subsidiaries under the 1916 Act would constitute NOI of benefits accruing to the European Communities, up to the cumulative dollar or monetary value of the final judgments'. However, there had not been any such judgment as of the date of the hearing so that, 'no such amounts could be included in any calculation of the level of NOI sustained by the European Communities'. 54 Similarly, settlement awards entered into by EC companies under the 1916 Act could not be included in the assessment of the level of NOI, as the amounts involved were not known because of confidentiality provisions in the agreements. ${ }^{55}$ Therefore, while the EC was authorized to suspend concessions up to the monetary value of future final judgments and future settlements if known, the permitted level of suspension as of the date of the hearing was zero.

It is understandable that the arbitrators placed more emphasis on the authorization of possible suspension in the future, than on what could be described as the suspension of the suspension remedy. There is something counter-intuitive about confirming that values protected by the covered agreements have been nullified or impaired, and then finding during suspension proceedings that there is no remedy available to induce the respondent state to observe the protected values. ${ }^{56}$ For present purposes however, it need only be noted that this is a problem which will occasionally arise both under the approach to DSU Article 3.8 defended here, and under WTO law and practice as it presently stands. Based on the discussion in this section, there seems to be overwhelming evidence that the concept of

54 Ibid paras 6.4-6.5.

55 Ibid paras 6.7-6.10.

56 The occurrence of the problem is made less likely by the complexity of WTO disputes brought about by the tendency to make multiple claims under different covered agreements. In any given case, quantifiable trade damage caused by one or more of the offending measures will most likely be found, to which the suspension remedy can attach, even if the same cannot be said of all the successfully challenged measures. Thus while GATT violations were confirmed by the Appellate Body in the EC - Bananas III dispute, no part of the ensuing authorization of suspension could be based on these violations as the United States was not an exporter of bananas. However, suspension was authorized up to the amount of US $\$ 191.4$ million per year based on the GATS inconsistent aspects of the measures; specifically the impact on the United States' share of wholesale trade services sold in the European Communities and on the United States' share of allocated banana import licenses. The author is grateful to Simon Lester of http://www.worldtradelaw.net for clarifying this point. Decision by the Arbitrators, European Communities - Regime for the Importation, Sale and Distribution of Bananas - Recourse to Arbitration by the European Communities under Article 22.6 of the DSU (9 April 1999), WT/DS27/ARB, para 7.8. 
NOI is understood in two different senses. The distinction is captured in the following third party submission by Japan:

The WTO jurisprudence indicates that the concept of 'NOI of a benefit' is not limited to trade losses of the complaining party but also include broader interests accruing under the WTO rules. However, the 'level of NOI of a benefit' in the context of the authorization of suspension of concessions or other obligations is rather determined based on trade effects. $^{57}$

\section{B. An infringement constitutes a case of NOI}

The second element of the suggested approach is that, if an infringement of a provision is established, there is necessarily a NOI of the benefit protected by the provision. An infringement therefore constitutes a case of NOI, rather than just a prima facie case. In the introduction, it was noted that, in reality, if not always in appearance, the process of deciding whether there is NOI is an integral part of the analysis of whether there is an infringement. This section elaborates on the qualification in this sentence.

There is a tendency in the case law to end the analysis with a separate discussion of NOI, sometimes using this term as a heading. Typically, this follows on from the analysis of whether specific provisions have been infringed. It is this structure which can lead to the misapprehension that the closing material adds to, and is conceptually distinct from, the material which precedes it. The reality is that, frequently, very little at all is said under the heading of NOI. In cases where there is some discussion, it could just as well be incorporated within the infringement analysis. The following cases are representative of those which illustrate these points.

In cases where there has been no attempt to rebut the DSU Article 3.8 presumption, the provision has been interpreted as if it establishes an absolute rule that an infringement constitutes a case of NOI. Having cited Article 3.8, the Appellate Body in US - Offset Act (Byrd Amendment) concluded that to the extent that inconsistencies between the challenged Act and a number of the covered agreements had been found, the Act 'nullifies or impairs benefits accruing to the appellees in this dispute under those Agreements'. 58 The panel in the later case of EC - Tariff Preferences adopted the same approach. Again, having cited Article 3.8, the panel stated that, '....because the Drug Arrangements are inconsistent with Article I:1 of GATT 1994 and not justified by Article 2(a) of the Enabling Clause or

${ }^{57}$ WTO Panel Report, European Communities - Regime for the Importation, Sale and Distribution of Bananas - Recourse to Article 21.5 of the DSU by the United States, above n 52, paras 5.2315.232-notes omitted.

${ }^{58}$ WTO Appellate Body Report, United States - Continued Dumping and Subsidy Offset Act of 2000 (adopted 27 January 2003), WT/DS217/AB/R, WT/DS234/AB/R, para 304. 
Article XX(b) of GATT 1994, the European Communities has nullified or impaired benefits accruing to India under GATT 1994'.59

In cases where there is an attempt to rebut the presumption, the redundancy of the nullification concept is not so immediately obvious. This is because there is at least some material under the heading of NOI which did not appear in the earlier analysis of the existence of infringements. However, the apparently additional material relates to the nature of the benefits protected by the provisions in question, and merely explains why the provisions have been infringed. Therefore, the additional material could just as well be incorporated within the infringement analysis. The Appellate Body recently stated as follows in the EC - Bananas III compliance hearing:

Having found that the preferential ACP tariff quota was inconsistent with Articles I: 1 and XIII, the Panel addressed the question of NOI in a separate section at the end of the US Panel Report. Relying on panel and Appellate Body findings in the original proceedings, the Panel found that, considering that 'WTO rules are not concerned with actual trade effects, but rather with competitive opportunities', the United States, as a potential exporter of bananas, had suffered NOI because of the European Communities' inconsistent measures. ${ }^{60}$

Therefore, there were infringements, and there was NOI because of the nature of the benefits protected by the infringed provisions. A description of these benefits does not belong uniquely to a discussion of NOI. The more natural context is within the infringement analysis.

A few words can be added here to explain how the existence of the non-violation complaint reinforces the argument that an infringement constitutes a case of NOI. ${ }^{61}$ GATT Article XXIII:1(b) envisages that the benefits accruing under the Agreement can be nullified or impaired not only by infringements, but also by 'the application by another contracting party of any measure, whether or not it conflicts with the provisions of this Agreement'. The non-violation complaint is preserved by DSU Article 26:1 and extended to the covered agreements. The proposition that there is always NOI whenever there is an infringement, is not undermined by the possibility that there can also be nullification without an infringement. It is

${ }^{59}$ WTO Panel Report, European Communities - Conditions for the Granting of Tariff Preferences to Developing Countries (adopted 20 April 2004), WT/DS246/R, para 8.1(f).

${ }^{60}$ EC - Bananas III (Article 21.5 - EcuadorII)), EC - Bananas III (Article 21.5 - US)), above n 1, para 466.

${ }^{61}$ On the non-violation complaint, see Ernst-Ulrich Petersmann, 'Violation-Complaints and Non-Violation Complaints in Public International Trade Law', (1991) 34 German YB Int'1 L 175; Roessler (above n 32); Thomas Cottier and Krista Nadakavukaren Schefer, 'Non-Violation Complaints in WTO/GATT Dispute Settlement: Past, Present and Future', in Ernst-Ulrich Petersmann (ed) International Trade Law and the GATT/WTO Legal System, Studies in Transnational Economic Law, volume 11 (Kluwer Law International, London 1997) 143-83. 
this possibility which explains why the concept was carried over into the GATT from bilateral trade agreements entered into by the United States in the 1930s and 1940s. ${ }^{62}$ As Hudec noted, the NOI clause 'was developed to deal with government measures, not covered by the agreement, which frustrated the anticipated commercial benefits of tariff concessions'. ${ }^{63}$ It would seem to follow that for government measures which are covered by the WTO agreements, the nullification concept has no separate and additional function once a violation is confirmed.

This appears to have been the understanding of the drafters of the General Agreement on Trade in Services (GATS) as evidenced by the structure and content of Article XXIII on Dispute Settlement and Enforcement. The NOI language is used only in paragraph 3 which deals with the non-violation complaint. In contrast, it is absent from paragraph 1 which deals with the violation complaint in these terms:

If any Member should consider that any other Member fails to carry out its obligations or specific commitments under this Agreement, it may with a view to reaching a mutually satisfactory resolution of the matter have recourse to the DSU.

This contrasts markedly with GATT Article XXIII, in which both the violation and non-violation complaints are brought under the umbrella of NOI.

\section{Article 3.8 operates during suspension proceedings}

The third element of the suggested approach is that Article 3.8 should be interpreted as operating at the commencement of suspension proceedings, rather than immediately after the infringement analysis. Support for this position can first be gained from continuing the discussion at the end of the previous section. The formal irrelevance of the NOI concept in violation complaints under GATS Article XXIII:1 means that DSU Article 3.8 cannot operate in GATS disputes during or immediately after the infringement analysis. At this stage of the proceedings, there cannot be a rebuttable presumption of something which is formally irrelevant. However, DSU Article 3.8 must be regarded as applying somewhere in GATS disputes. Its operation could only be excluded if, pursuant to DSU Article 1.2, there was 'a difference' between DSU Article 3.8 and 'the special or additional rules and procedures set forth in Appendix 2' of the DSU. In the event of such a difference, the special or additional rules prevail. GATS Article XXIII: 1 is not among the two GATS provisions which have the status of 'special or additional rules'. ${ }^{64}$ Assuming that this is deliberate, rather than an oversight,

\footnotetext{
62 On the origin of the NOI clause, see Cottier and Schefer, ibid, at 149-52.

${ }^{63}$ Robert E Hudec, The GATT Legal System and World Trade Diplomacy (2nd edn Butterworth Legal Publishers, New Hampshire 1990) 37.

64 GATS Articles XXII:3 and XXIII:3.
} 
the position is that GATS Article XXIII:1 and DSU Article 3.8 need to be interpreted so that they can co-exist harmoniously. This is achieved if Article 3.8 is interpreted as a presumption of NOI in the sense of adverse impact on trade flows which operates at the commencement of suspension proceedings.

More generally, this suggestion flows naturally from the hypotheses which have been explained and tested above. There is strong evidence that the term NOI is understood in two different senses. In cases where an infringement has been established, there is no evidence of there being a residual and conceptually distinct matter to be discussed under the heading of NOI. It follows that a rebuttable presumption of NOI operating when the issue of infringement is discussed, is unsustainable. In contrast, a rebuttable presumption of NOI in the sense of adverse impact operating at the commencement of suspension proceedings is sustainable. Infringements frequently have an actual impact on trade flows even though it may be possible for the respondent state to show the absence of such impact. This presumption is also consistent with the language of 3.8. It refers to a presumption of NOI in the sense of 'adverse impact', rather than a presumption of NOI of benefits accruing to the members under the covered agreements. Bearing in mind that this third element provides a means of making sense of DSU Article 3.8 as it is presently drafted, it is surprising to find little evidence of it in the case law. The prevailing view is rather that the presumption operates after the infringement analysis.

This view is illustrated by the following panel statement which was approved by the Appellate Body in the EC - Bananas III compliance hearing.

[t] he presumption of NOI in the case of an infringement of a GATT provision as set forth by Article 3.8 of the DSU cannot in and of itself be taken simultaneously as evidence proving a particular level of NOI allegedly suffered by a Member requesting authorization to suspend concessions under Article 22 of the DSU at a much later stage of the WTO dispute settlement system. ${ }^{65}$

This passage clearly establishes that Article 3.8 operates before Article 22 . To this extent, the passage contradicts the suggested approach. Significantly however, there is nothing here to undermine the view that Article 3.8 should be interpreted as operating at the start of suspension proceedings. To the contrary, the suggested approach is consistent with the main sentiment of this passage. The presumption would only provide the starting point that the infringement has resulted in an adverse impact on trade flows. The level of this adverse impact would remain to be decided.

${ }^{65}$ EC - Bananas III (Article 21.5 - Ecuador II)), EC - Bananas III (Article 21.5 - US)), above $\mathrm{n}$ 1, para 475. The extract is from Decision by the Arbitrators, above n 65, para 6.10. 


\section{RECOMMENDATIONS}

For the reasons explained in this article, DSU 3.8 should be interpreted as a rebuttable presumption operating at the commencement of suspension proceedings that an infringement results in an adverse impact on trade flows.

The final question considered here is whether it is reasonable to expect the dispute settlement system to adopt this interpretation, or whether amendments to the DSU should be contemplated. Based on the analysis above of the three elements of the suggested approach, it is perhaps not unreasonable to leave matters to the Appellate Body. There is strong evidence of the first two elements in the case law so that it could be just a matter of time before the final piece of the puzzle is slotted into place. This would not amount to an exercise in judicial activism as it amounts to no more than a sensible re-interpretation of the provision, rather than its amendment or deletion.

On balance, however, it is considered that it would be beneficial to add Article 3.8 to the DSU reform negotiations. ${ }^{66}$ This is because there are two distinct matters which need to be addressed. There is first a need to give effect to the original rationale identified by the GATT panel in Uruguayan Recourse to Article XXIII. This was to simplify the process by which complaining states can permissibly call for the establishment of a panel. As suggested above, paragraph 5 of the 1979 text, with its references to 'suspension of concessions' and 'adverse impact' does not resemble the type of the provision which would have given expression to this rationale. DSU Article 3.8 could therefore be replaced with a more straightforward statement that an allegation of an infringement constitutes an allegation of NOI. The second matter is for the correct interpretation of Article 3.8, as it is presently drafted, to be put beyond doubt. This could be achieved by inserting an additional provision in DSU Article 22 which would fit well as paragraph 3.

The text might then read:

In proceedings to determine the level of compensation or the suspension of concessions, there is normally a presumption that a breach of the rules has an adverse impact on other Members parties to that covered agreement, and in such cases, it shall be up to the Member against whom the complaint has been brought to rebut the charge.

${ }^{66}$ Information about the progress of these on-going negotiations and the proposed changes to the DSU is available on the WTO's web pages: < http://www.wto.org/english/tratop_e/dispu_e/ dispu_e.htm\#negotiations $>$ accessed 10 August 2009. The proposals made are compiled on the Georgetown Law pages: <http://www.law.georgetown.edu/iiel/research/projects/dsureview/ synopsis.html\#art3 > accessed 10 August 2009. The indications are that Article 3.8 has so far escaped the attention of the negotiators. 
So self-evident is the meaning of this provision that it could perhaps be omitted. However, in combination, the proposed changes would send clear signals about what arguments can permissibly be raised at different stages in the proceedings, and lead to a modest simplification of the dispute settlement process. 